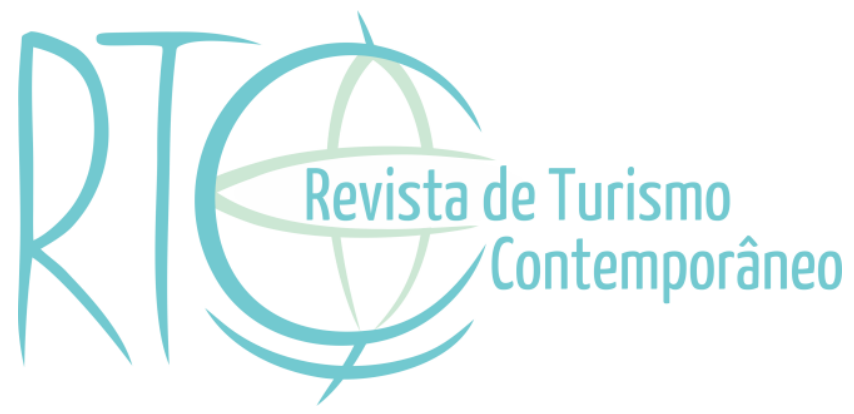

\title{
Tourist festivals and territorial development: a case study on the Jazz in Marciac Festival
}

\section{Festivais turísticos e desenvolvimento territorial: um estudo de caso sobre o festival Jazz in Marciac}

\section{Erick de Oliveira Faria}

Master in Geography by the Pontifical Catholic Federal University of Minas Gerais - UFMG, Belo Horizonte/MG, Brazil

E-mail: erickolifaria@gmail.com

\section{Victor Pouillaude}

Student of masters in Urbanism and Planning of the Territory by the University of Lille Lille/Hauts-de-France, France

E-mail: victor.pouillaude@gmail.com

\section{Valentine Crépel}

Student of masters in Urbanism and Planning of the Territory by the University of Lille Lille/Hauts-de-France, France

E-mail: crepel.valentine@icloud.com

\section{Manuella Biagioni Barbosa Teixeira}

Student of bachelor in Tourism by the Federal University of Minas Gerais - UFMG, Belo Horizonte/MG, Brazil

E-mail: manuellabiagioni@gmail.com 


\section{ABSTRACT}

From the year 1982, new possibilities were given to the spatial organization of the French territory. In these spaces, the actions of social groups are recognized. Therefore, the social group builds the territory but the environment in which it lives also influences it. This paper studies the case of the Jazz in Marciac festival as an example of territorial development associated with the dimension of the voluntary commitment of the population towards a common objective and a source of debate. This jazz festival takes place at the village of Gers, Marciac and is guided by the principles of popular education. Today it gives life to its territory through national and international recognition as one of the most recognized jazz festivals. This is why we decided to ask ourselves about the causes of success at the jazz festival in a French village. So the questions came out: what does this imply in terms of development at the scale of its surroundings? Why and how this festival contributed to authentic development to the extent of its territory. The territory of Marciac turned a music festival into a local development opportunity, by its strength for cultural tourism, the valuation of local heritage and the improvement of living conditions. So the festival has become a showcase for local productions and a driving force for regional planning, it improves cultural, social and economic aspects of its territory.

Keywords: Jazz Festival. Territory Development. Cultural Tourism. Popular Education.

\section{RESUMO}

A partir do ano de 1982, novas possibilidades foram dadas à organização espacial do território francês. Nestes espaços, as ações dos grupos sociais são reconhecidas. Portanto, o grupo social constrói o território, mas o ambiente em que vive também o influencia. Este artigo estuda o caso do festival Jazz in Marciac como um exemplo de desenvolvimento territorial associado à dimensão do compromisso voluntário da população para um objetivo comum e uma fonte de debate. Este festival de jazz tem lugar na aldeia de Gers, Marciac e é guiado pelos princípios da educação popular. Hoje dá vida ao seu território através do reconhecimento nacional e internacional como um dos festivais de jazz mais reconhecidos. É por isso que decidimos nos perguntar sobre as causas do sucesso no festival de jazz em uma vila francesa. Então, as perguntas surgiram: o que isso implica em termos de desenvolvimento na escala de seu entorno? Por que e como este festival contribui para o desenvolvimento de seu território? O território de Marciac transformou um festival de música em uma oportunidade de desenvolvimento local, por seus pontos fortes para o turismo cultural, a valorização do patrimônio local e a melhoria das condições de vida. Assim, o festival se tornou uma vitrine para produções locais e uma força motriz para o planejamento regional, melhorando seus aspectos culturais, sociais e econômicos de seu território.

Palavras-chave: Jazz Festival. Desenvolvimento Territorial. Turismo Cultural. Educação Popular. 


\section{INTRODUCTION}

While the Fordist vision of the economy influenced the planning of the territory, valuing urban areas over rural areas, the decentralization laws of the year 1982 gave new possibilities to the spatial organization of the French territory (Amin \& Robins, 1990). These spaces, by considering them again as territories in the noble sense of the term, are a geographical area where the actions of a social group are recognized. The social group builds the territory, but the environment in which it lives also influences it.

The sense of expropriation of the environment is, therefore, following the reappropriation. This allows the possibility for the social groups to express themselves, to become actors of the changes that occur in their territory (Melucci, 1980). Local development appears this development refers to all the economic actions that concern a small space (in comparison with national or regional spaces) (Henderson, Dicken, Hess, Coe, \& Yeung, 2002). Summarize the development in its economic sector and the geographical area made us forget that development also affects individuals living in the space. Then emerges the notion of territorial development that is associated with the dimension of the voluntary commitment of the population towards a common aim and a source of debate (Oakley, 1991).

This is how The Marciac Jazz Festival was born through the will of Marciac citizens, and it is thanks to them that the festival has become a reference in jazz music, making Marciac a jazz territory. Marciac, is a village at the Gers, was subject to some problems like many other rural villages. Between the demographic decline and the difficulty in maintaining public services, Marciac was not an attractive and dynamic village and had none characteristics related to jazz yet. Things started to change when a group of people were passionate about jazz and intended to share it in the village under the principles of popular education.

\section{JAZZ IN MARCIAC: A CITIZEN AND CREATIVE INITIATIVE}

The Marciac Jazz Festival was born through the will of Marciac citizens, and it is thanks to them that the festival has become a reference in jazz music, making Marciac a jazz territory. Marciac, is a village at the Gers (map 1), was subject to some problems like many other rural villages. Between the demographic decline and the difficulty in maintaining public services, Marciac was not an attractive and dynamic village and had none characteristics related to jazz yet. Things started to change when a group of people passionate about jazz and intended to share it in the village under the principles of popular education. 
Thus, this group engages in the legal form of an association resulting from this movement, which contributes to the innovative character of this festival. Now this association has forty members. We can notice that the principles of popular education have been maintained despite the considerable development of the festival. These are the same members of the Foyer de Jeunes et d'Education Populaire (FJEP) who launch a cultural event. Since then, the project has a double aim: to give to the inhabitants the material to work in their village and to attract some outside residents to the concert period.

The association statutes are also clear about the role of Jazz in the project: "This association aims to promote jazz music and culture in rural areas" (Vincent, 2005). It is affiliated to the LFEEP (Ligue Française de l'Enseignement et d'éducation Permanente) through the FALEP (Fédération des associations Laïques d'Education Permanente) of the Gers (Vincent, 2005). Although there are economic benefits and the fact that the festival is not free, the goal is absolutely not lucrative. The choice of free is still an illustration of the values of popular education by allowing not limiting jazz to the starter people. 
Map 1 - Place of Festival

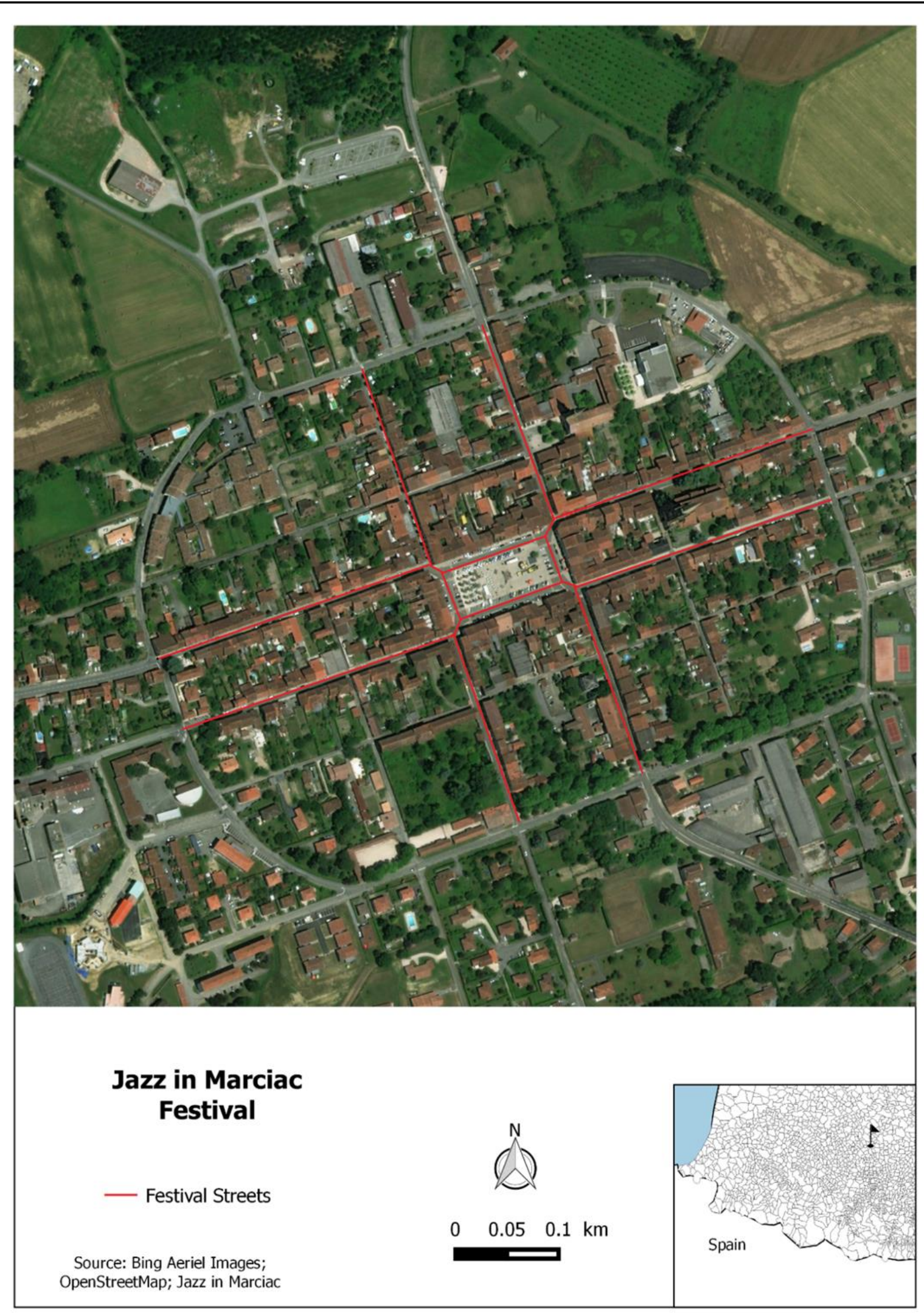

Source: Prepared by the authors, 2019. 
However, the development of such a project was not made without difficulties. At the head of this association, Jean-Louis Guilhaumon, the school's director, became the village mayor and the vice president of the Regional Council, and then he was transferred from Marciac for no particular reason. Within the association, many confrontations and compromises have been made in the framework of a participative democracy, where everyone can express themselves and vote.

\subsection{One social innovation}

The values of popular education, and sometimes the values of jazz, are carried by the project and appropriated by the inhabitants. Thus, they are part of the project by bringing their knowledge and know-how to the festival.

A member of the FJEP assured the sound of the first concerts. In the premises of the event, the inhabitants provided the meals of the musicians, and some people even hosted some artists. The treasurer of the Jazz in Marciac association, Jean-Claude Lasserre, says that the festival could not take place without the volunteers' actions since the festival's budget is only 2.5 million euros (Pyrda, 2014). This volunteer commitment is considerable; some even take 15 days to carry out their actions. It is even to say that the commitment by these volunteers seems to result from joining the project, and not necessarily only about the jazz. Those who work to make JIM work well know that this project is global, includes many areas, and is, in fact, a real engine of local development, even a cultural, social and economic enterprise.

\section{IT BECAME A JAZZ TERRITORY}

The identity of the Gers is built on several elements such as its bucolic setting and Gasconne gastronomy, including foie gras for example. The image of the Gers is popularized in the movie "Le bonheur est dans le prê" where is emphasized the fact of the good life at the Gascon country.

That is why, in Marciac, it can be quite surprising to see how music considered urban is so well integrated into such a rural area. However, there is no inconsistency for the professional bassist Pierre Boussaguet, who explains that the rhythm of this music, more "laid-back" (slightly behind time) corresponds to the final rhythm of life as in the Tarn or in the Gers. "It comes from people of the land", he added (Fontorbes \& Granier, 2004).

Thus, although there seems to be no connection between Marciac and the jazz at the origin, it is the values granted to this music (such as the mission of popular education) that 
integrate jazz in the territory of Marciac and that allow the inhabitants to appropriate the event.

The festival does not replace or destroy the Gers identity: it develops and integrates it. This built territory is then represented as a wine territory but also a jazz territory. This double identity is physically and concretely registered in the territory. The Gersoise identity is already inscribed in the countryside landscapes and in the soil, it combines perfectly with the Jazz and the festival. For example, the people involved with the festival who sponsor a vine are invited to come to the Colline de la Biste and can thus discover their feet and the names of jazz musicians registered on each row.

Also, introductory workshops on jazz music at the Marciac College were created in 1993. A real novelty in Marciac and even in France, the booklet clearly explains its aim, once again linked to popular education: "Music educates and builds the child. The musical group forms and structures". The purpose of the workshops is therefore really to open up the students to new music, to teach them and to attract students from other villages.

In this workshop is added the choice of a festival Off, which allows welcoming free those who want to discover the festival and the jazz, but also master classes made by artists invited to the JIM. Also, the construction of a new auditorium in 2001, the Astrada, allows to invite more artists and therefore to do more concerts to share Jazz music.

In addition, the museum "Les territoires $d u J a z z$ ", specified as being for the entire audience in the Marciac tourist office website, marks the integration of Marciac in all the territories of the Jazz and the will to sensitize and to educate to this music. This museum reveals the desire to put Marciac at the center of the jazz.

Finally, there is also a statue of the festival sponsor: Wynton Marsalis on the central square of the Chevalier d'Antras. It is possible to see an extract of the piece of his composition, named as "Marciac Suite" engraved in the slabs of the square. The Jazz is thus inscribed in the public space.

\subsection{A territory with different spatial references federated by the myth and the spirit of the Marciac's region}

With the festival, Marciac relates to the other jazz territories and thus has other territorial references. Alain Lefebvre and Robert Boure explain it very well in their article: "La médiation culturelle du territoire: l'exemple de trois festivals en milieu rural" (2000). In the study case of Marciac, the village is connected to the region (the Gascogne image and the 
main customers of JIM), to Europe (cultural tourism) and finally to the America of Jazz (the nationality of the main invited artists). During the 15 days of the festival, there is a diversity of people of all ages, nationalities and social backgrounds and therefore it creates social proximity between them, even if there is no territorial proximity. So, the festival is a real creator of social ties within the village, all year long, but also among jazz and the people involved with the festival. The fame of the festival disturbed the development strategy and transformed the space in which it is located.

\section{A FESTIVAL FOR THE LOCAL DEVELOPMENT}

From the identification of jazz, the territory was born a way to develop the territory. The festival has become a way to support local development. Being a showcase for local productions and a driving force for regional planning, the festival enjoys its reputation for generating development. Local policies show a real willingness to guide development through tourism. Also, this tourism is cultural tourism it bases which on what the festival has accomplished so far by keeping it in its position but also by highlighting other things.

Taken in its entirety, the festival of Jazz in Marciac values a specific culture to the territory on which it takes place. Through gastronomy and a certain art of living, Gascon culture can express itself thanks to the podium that makes up the festival. During all the festivities we can find mainly two temporary restaurants promoting local gastronomic products. Because the appointment of JIM is not exclusive to the simple musical fact, but it is also an appointment with the culinary. Farmers of the region are invited to present their productions during the festivities.

The culinary art also reflects a lifestyle. The Gascon culture in its entirety is expressed through the festival. The festival is just as valued as the fairs that are found elsewhere in neighboring countries, where they transmit the art of conviviality and good living. Some representations of bullfighting happen in the village arena during the festival. The Gascony art of living promotes a different temporality from the urban environment, which is the strength of the festival. They talk about the "quart d'heure gascon" to designate any delays in appointments. This is one reason why the festival remains so popular, it knows how to keep the culture and the typical art of the Gers. It is not uncommon for volunteers to gather around a glass of alcohol after a morning of work and cheerfully invite anyone who passes by. After 40 years of existence, the Jazz in Marciac festival knew how to preserve the innocence of a good glass among friends despite its international success.

The Festival in Marciac is not just for jazz, but also for temporality, besides the 
Gascon culture, the art of taking time. The cultural expression is valued as a whole. That is why we find a policy that is voluntarily directed to all forms of expression. In Marciac we can find out of season the jazz museum "Les territoires du jazz", but also art galleries presenting the local artists (A l'âne bleu, L'Espace Eqart).

\subsection{An oversized festival?}

The 180,000 visitors attracted by an event of this magnitude raise many questions about the resources available to meet the demand. That is why Mariette Sibertin-Blanc supposes that such an event would be oversized in face of the territory's capacity. The consequences would be that the offer present on the territory could not adequately respond to the festival's request. Thus, territorial development would be impaired by the arrival or the use of large foreign companies that can respond correctly to the demand.

The question of housing in Marciac during the festivities is crucial. Over the years, the public has grown but not as much as the supply of housing. Thus, the inhabitants of the village are invited to take part in the collective effort once again by offering to host the people involved with the festival. This situation has made the happiness of several hosts who can afford an additional income through the festival. But it also made the happiness of the tourist promoter Pierre et Vacances which has notably inaugurated a new residential district intended for the tourists: the lake village in Marciac.

\subsection{Marciac: a holiday village?}

Among the fears and limitations to this model of tourism development is the syndrome of ghost towns off-season. Like ski resorts or seaside towns that do not keep a perennial population or very few people when the beautiful days are not there. This is why, since the 1970s, there has been a growth of second homes in the village of Marciac (Sibertin-Blanc, 2011). This corresponds to a stream of people who came to buy a house in the village to enjoy the summer festival during their holidays. We might think that this contributes to the desertification of the off-season village, but the peculiarity of the Marciac territory is to take advantage of its disadvantages. The territory has indeed adopted a resilient attitude that allows micro-regulation on a local scale. 


\subsection{A communal development: complete center redesign and renovation}

The village and the mayor know how to play the notoriety of the festival to call for help to renovate the village center. The village of Marciac in its document entitled " $D e$ l'impact d'un événement culturel sur son environnement" available on its official website identifies what it allowed thanks to the success of the festival. It is the improvement and the renovation of the center of the village is at stake. Finally, Marciac could present a rejuvenated face and at the height of his attendance thanks to the background provided for the contract "Site Majeur".

\subsection{Maintenance of the college}

While it questioned the durability of the college of Marciac, it was the jazz that allowed its maintenance in the village. Not wanting to see his college disappear with all the consequences that this implies (demographic loss, destruction of jobs, loss of vitality and dynamism because of the lack of youth in the village), Jean Louis Guilhaumon had the idea to integrate a jazz section. In 1993, the jazz class of the college opened, which plans to educate and sensitize students about jazz music but also to practice an instrument (Collège de Marciac, 2010). In addition, students enjoy opportunities to represent themselves on various occasions, but mainly during the festival of Marciac on the village square in front of the spectators from the off festival. Thus, the college doubled its population and the village responded to the demographic challenges that threatened it out of season.

\subsection{Health Center}

In Marciac, the inhabitants have the benefit of a health home built ex nihilo since 2011. Because of the presence of medical equipment and specialists, the population of Marciac and its surroundings have the benefit of health services (Serres, 2014). Thus, without the precipitation and the affluence that allows the party in the city, the emergence of this health center was allowed in a commune that counts with only 1.247 inhabitants (Institut National de la Statistique et des Études Économiques - INSEE, 2015). So it rebalances the territory in terms of health services and reduces health-related travel in rural areas, which is also a problem that many French rural communities are suffering. 


\section{EDUCATION INSTITUTIONS}

\subsection{Grand Site Occitanie}

The label Grand Site Occitanie is a seal granted to notable spaces in the region. Responding to the project request, Marciac again recognized its heritage and emphasized the importance of the tourism economy in its development. Enjoying the label, the village also profits from the visibility for tourists, but also from the financial and technical support to keep its place in a qualitative offer. Thus, the region and the municipality of Marciac take part in the economy's improvement health of the territory. However, before receiving this recognition, Marciac had to show that it could develop a strategic territory project and organize governance in its territory in the project's direction (Direction du Tourisme et du Thermalisme, 2018). The recognition of higher institutions allowed Marciac to continue building itself.

\subsection{Pole of rural excellence}

Like the Grand Site Occitanie certification, the pole of rural excellence is an acknowledgment of the DATAR attributed to the rural territories to reinforce them in their will to develop. It must present orientation of patrimonial, cultural or touristic valuation. In Marciac, the seal participated mainly in the financing of a theater's construction in 2015 . It is found today in the city of Marciac under the "Astrada". The Astrada is, therefore, a concert hall that operates during the festival period as a third stage (after the marquee and the festival), but not only. The goal is to perpetuate cultural activity throughout the year by offering an artists program to attract more and more viewers in connection with the jazz environment.

\subsection{The department hears the creative initiatives of social and solidarity} economy

The Gers department shows it knows how to listen to its territory and provided a framework that is part of the continuity of the JIM. The department, through the creation of a Chambre Régionale de l'Economie Sociale et Solidaire (CRESS), listens to citizens initiatives and is placed in a Pascalian vision of territorial development described by Labbé (2012). He describes a caring attitude on the part of institutions to make employment emerges from what individuals want to do. In opposition to a cartesian view that tries to reconcile employment with the project that institutions decided to implement. 
In addition, the Department of Gers seeks to highlight the territorial particularities of its faculties and concerns deriving from the festival, such as the development of culture through the creation of theater section (Auch, Mirande), music (Marciac) or the environment (Aignan).

The territory of Marciac turned a music festival into a local development opportunity. It is the cultural tourism that has been chosen as the main guideline, but this is only a pretext to deeply transform relationships and to move towards a common direction

\section{A DEVELOPMENT THAT REMAINS TERRITORIALIZED}

In addition, enterprises, inhabitants, volunteers, and the association "Jazz in Marciac" work together in a complementary way. It is possible to talk about connivance among the actors, who are therefore working in a "win-win" relationship. The case of the "Plaimont" wine group illustrates this form of partnership well.

In fact, today, one of the main actors in the production of vineyards in the southwest of France, Plaimont, has been working with the association since its earliest days. The cooperation is done through the creation of a harvest entirely dedicated to the festival which will be appreciated for free by the people involved with the festival. In addition, the wine group also sponsors parties that take place under the marquee. Within the festival, the Plaimont offers a free concert at the Château de Sabazan, which is accompanied by other educational activities for the public to discover the land.

At first sight, the JIM association does not perform any direct service to the wine group. However, the festival is a real gateway to an international market. The festival allows Plaimont to sell and to promote its products to a diverse and international audience. The vineyards' sponsorship by the people involved with the festival is also an advantage that the festival offers to the wine group.

On the way out of the capital, on the way to the village square, the Summer School of Rural Innovation of Marciac is performed. Taking the form of discussion circles or academic conferences, but also associations, citizens and festival visitors have the words at the time of the festivities. It is questioned the place of the rural world in our society, the choice of the economic and the social model for future generations. It compiles the sum of the reflections in a document "Les Actes", to put in black and white what was said during the meetings and bring some reflection beyond the festival borders. 


\subsection{Public communication and information}

Over the years, the festival could develop abundant communication. The communication of the festival is present on all fronts. To promote communication, the graphic chart reveals real research work. It is found in a variety of media such as posters, clothes, objects.

The most surprising fact is the information transmission diversity that is retransmitted because, in fact, we do not only find the festival schedule. The JIM association transmits a lot of information that does not belong directly to the festival. Several information media are used for the visitor to be informed about the diversity of the events that occur during the festivities, but also to contextualize where they are. It is possible to find mainly the brochure "Marciac in the Pocket", which extends to the whole city the promotion of the event during the festival. The work of other associations is also valued thanks to the festival transmission efforts. This reveals real genuine solidarity between the different sectors.

Environmental issues are at the heart of the festival and territorial project concerns. The festival is committed to an ecological citizenship approach by adhering to a letter that is committed to thinking about waste management. A parallel event is also organized at the festival. It is called Paysages in Marciac and is intended to raise awareness for the landscape reading through hiking in the territory and conferences.

To meet the requirements of each one of the actors of the territory, the mixed union of the Pays du Val d'Adour was then constituted. Pays $d u$ Val d'Adour is a group of communities of communes in order to share the development of each commune around the identification of mobilization projects in the territory. Its originality is in its mode of operation and in the territory in which it fits. The members of the union belong to the following communities of municipalities: Community of communes Armagnac Adour; Community of communes Bastides et Vallons du Gers; Community of communes of the Nord-Est Béarn; Community of communes Adour Madiran.

The originality of this composition is that these communities do not all belong to the same departments or regions. The region of Occitanie and the region of Grand Aquitaine, as are the departments of Gers, Haute-Pyrenees and Pyrénées Atlantiques. It is important to note that this goes against the view of prescribed territory as the French state conceives it. Here the territory presents a form built by the need to act together for a common goal.

This translates into a voluntarist mode of action. The center of territorial and rural balance of the Pays du Val d'Adour operates on the basis of the voluntary involvement of its 
participants. These members are signatories to a letter of commitment, which means that there is no regulatory obligation, but all the stakeholders are committed to respecting it. The compromise is then contracted to spread the agreements in the territories.

Thus, the actors of the territory understood that it is not by confining the ruling class in a technocratic sphere that we maximize the development, it constituted a council of development. It consists of a sample of the population that is representative of all the dynamics that occur in the territory. That is why we find actors from the associative world, professionals, or even citizens. The council is consulted to give its opinion on the instructions to be taken for the territory. This requires the territory to update and take into account the concerns and expectations of each in the realization of the common project.

At the head of the country, we find the personality of Jean-Louis Guilhaumon. He carries the political project of the territory from the beginning, demarcating with every imaginable institution the project of the territory. The convergence of forces towards a common goal that is clearly identified and mainly includes: tourism and cultural development; valuation of the local heritage; improvement of living conditions.

Using all the local resources to carry out a common project, the festival made it possible to reach everyone's expectations beyond the field of music. It is the affirmation of a territory and its appropriation that allowed such citizens initiative.

\section{CONCLUSIONS}

Marciac is primarily a music festival, it has become a territory of jazz (piano touch and copper opening in the illustration). This music festival based in villages has become a reference in jazz music over the years. What makes it a complete festival is also the will and the dynamism of those who make it lives. This is mainly based on voluntary involvement and is strongly marked by the principles of popular education. Jazz in Marciac is a festival of citizenship, it is the sense of responsibility towards others and its territory that gives it so much depth.

The festival became an object and a subject of development at the same time. In this drawing, the Marciac bastide is represented as an urban center capable of attracting a population flow and managing it without difficulty. Here we find the idea that the territory has adapted to allow the maintenance of the festival, but it also became the element that spread a wealth of economic, cultural and social factors. The density of relationships and convergent productions, thanks to the festival and a common goal, shows that this is how we can advance 
listening to the interests of each one.

This is how many people, inhabitants, locals, volunteers, traders find their interest and work for the festival in a "win-win" relationship. Without all the small actions done by the locals, the festival certainly would not have happened, or it would not have this friendly spirit and the values of popular education. We can even think that a festival like Marciac is so anchored in this village that it could not have existed elsewhere, without the human strength of this village.

But still, what we can see here is the presence of campaigns around the bastide. The transformations induced by the festival in the territory of the Marciac region remained strongly marked by their own identity. It is, therefore, a density of activity that we find in this rural world. Today the territory also knows how to listen to the initiatives that are born in its territory, preserving the territorial culture, but always offering a new point of view that extends it.

It is possible to think that Marciac becomes a model of planning of the new rural world, nevertheless, the Jazz in Marciac festival shows that it represents a model of an individuals organization. This organization mainly serves the territory, by its environment of life and by the people that constitute it.

\section{REFERENCES}

Amin, A., \& Robins, K. (1990). The re-emergence of regional economies? The mythical geography of flexible accumulation. Environment and Planning D: Society and Space, 8, 734.

Collège de Marciac. (2010). Fonctionnement des Ateliers d'Initiation à la Musique de Jazz. (AIMJ). Retrieved May, 25, 2019, from Collège de Marciac website: http://marciac.entmip.fr/bienvenue-au-college/classe-jazz/

Direction du Tourisme et du Thermalisme. (2018). Appel à projets - Grands sites Occitanie. Retrieved May, 15, 2019, from Portail de Région Occitanie website: https://www.laregion.fr/Appel-a-projets-Grands-sites-Occitanie

Fontorbes, J. P., \& Granier, A. M. (2004). Le village qui fait Jazzer [Documentaire, Film]. Henderson, J., Dicken, P., Hess, M., Coe, N., \& Yeung, H. W. C. (2002). Global production networks and the analysis of economic development. Review of International Political Economy, 9, 436-464.

Institut National de la Statistique et des Études Économiques - INSEE. (2015). France et ses territoires. Collection INSEE Références Edition. 
Labbé, P. (2012). L'accompagnement socioprofessionnel (ASP): Une construction systémique. Cahiers de l'action, 37(3), 13.

Melucci, A. (1980). The new social movements: A theoretical approach. Social Science Information, 19, 199-226.

Oakley, P. (1991). Projects with people: the practice of participation in rural development. Geneva: International Labour Office

Pyrda, P. J. (2014). 2014 a été une année faste pour JIM. Retrieved April, 10, 2019, from Ladepeche website: https://www.ladepeche.fr/article/2014/12/21/2015772-2014-a-ete-uneannee-faste-pour-jim.html

Serres, M. (2014). Marciac. La maison de santé est ouverte. Retrieved May, 23, 2019, from Ladepeche website: https://www.ladepeche.fr/article/2014/01/01/1785788-marciac-la-maisonde-sante-est-ouverte.html

Sibertin-Blanc, M. (2011). Développement de la culture, développement du territoire: une ambiguïté au cœur du festival Jazz in Marciac? In Développement culturel et territoires. (1st. Ed.). Retrieved from https://halshs.archives-ouvertes.fr/halshs-01025115

Vincent, P. (2005). Le Festival Jazz in Marciac et la notion d'engagement: un évènement fédérateur. Retrieved from http://doc.sciencespolyon.fr/Ressources/Documents/Etudiants/Memoires/Cyberdocs/MFE2005/vincent_p/pdf/vinc ent_p.pd

\section{FORMAT FOR CITATION OF THIS ARTICLE}

FARIA, E. O., POUILLAUDE, V., CRÉPEL, V., \& TEIXEIRA, M. B. B. (2020). Tourist festivals and territorial development: a case study on the Jazz in Marciac Festival. Revista de Turismo Contemporâneo, 8(1), 1-16. https://doi.org/10.21680/2357-8211.2020v8n1ID18098 